\title{
EVALUATION OF STUDENTS' LEARNING OUTCOME: AN EXPERIENCE SHARING TEACHING AGRIBOTANY AT SULTAN IDRIS EDUCATION UNIVERSITY, MALAYSIA
}

\author{
Mai Shihah Abdullah* \\ *Dr., Senior Lecturer, Department of Agriculture, Faculty of Technical and Vocational Education, \\ Sultan Idris Education University, MALAYSIA, mai.shihah@fptv.upsi.edu.my
}

\begin{abstract}
UPSI is dedicated to become the Leading Education University in Malaysia's tertiary education system and has moved towards Outcome-based Education (OBE) approach since 2008. The ultimatum of the OBE focuses on the graduate attributes or program learning outcomes (PLO) upon completion of an academic program. However, while colleagues from other Higher Education Providers are sceptical about the implementation of OBE with the perception that it requires lots of time and effort, but with the integration of technology in teaching and learning at UPSI, Course Learning Outcome (CLO) calculation is very handy. The prescribed PLOs are first aligned to the all CLOs designed into the curriculum. Nevertheless, teaching and learning strategies and supporting facilities are also predetermined to support the intended outcomes. Students' achievements based on their performance in assessments are to be measured throughout the study. All these, make teaching a burden to the academic staff until UPSI introduced two platforms; MyGuru ${ }^{2}$ where course outline including the course learning outcomes (CLO), teaching materials, assessments and student-instructor online communication such as forum are uploaded and managed by the course instructor. MyGuru $^{2}$ is linked to the second platform, the University Integrated Management System (UIMS) where all assessments (formative and summative) data are analysed. At the end of the semester the evaluation of each course learning outcome mapped to the students' performance is displayed. In this paper, the author would like to share her experience teaching Agribotany, a course in Bachelor of Education (Agricultural Science) with Honours which was made easy by using these platforms. Thus, when the full cycle of a program is completed, CLOs of all courses which are mapped to Program Outcomes (PO) are analysed. The achievement of the Program Educational Objective (PEO) is the reflection of the quality of graduate of a program. It will further use in the Continual Quality Improvement (CQI) process.
\end{abstract}

Keywords: Course Learning Outcome, Program Learning Outcome, Sultan Idris Education University (UPSI)

\section{INTRODUCTION}

William Spady in 1994 has developed an outcome-based education (OBE), an education system that emphasizes on outcomes measurement rather than the inputs of the curriculum covered. Outcomes include knowledge, skills and attitudes. The desired outcomes are feasible when teaching and learning activities are well organized, planned and continuously improved (Spady, 1998; Spady and Marshall, 1991). OBE has also been described as a process of clearly focusing and organizing curriculum, instruction and assessment essential to enable students to do successfully at the exit point, with desirable criteria should be displayed. 
OBE is introduced and being implemented in Malaysia, both at the Public and Private Universities and Colleges since 2005. The paradigm shift is driven by Malaysian Qualifications Agency (MQA) to ensure the academic programs, the delivery system and the assessment strategies will produce graduates equipped with high quality knowledge and skills.

Assessment is the tool to reflect the achievement of PLOs as well as the process of continuous quality improvement (CQI). Although it has been introduced for almost 10 years ago, but many lecturers find that the assessments for Student Learning Outcome (SLO), Course Learning Outcome (CLO), Program Learning Outcome (PLO) are rather burdensome and lots of energy is invested to keep track the performance of OBE for a particular Program. By all means, it has to be done continuously for CQI and to ensure the program is awarded with MQA accreditation. The whole process of SLO, CLO and PLO assessments are reflected to be very tedious among lecturers; for example the mapping of CLO to PLO, the mapping of course assessment to CLO and the most cumbersome is the calculation of SLO, CLO and PLO. These are due to insufficient guide and unreadiness of lecturers to adapt to the newly introduced OBE.

At Sultan Idris Education University (UPSI), the same scenario occurred when undergraduate and post graduate programs curricular were transformed to the needs of the Malaysian Qualification Framework, introduced by MQA in 2008. The implementation is enforced on all the 37 programs offered by 9 faculties which include the Faculty of Technical and Vocational Education. There are three academic programs at this faculty, including the Bachelor of Education (Agricultural Science) with Honours. In this program, the curriculum structure comprises of five components with minimum graduating credit of 130; Higher Education Provider Courses (10-15\%), Education Foundation (17-25\%), Discipline Core (28-36\%), Professional Practice (7-12\%) and Elective (related to discipline core (15-18\%) or open (7-10\%).

Although at the primordial stage was not a smooth sailing journey, but sufficient information is provided by the University, added with the necessary foundation; conceptual understanding, planning, implementation, assessments/evaluations on which the CQI can be implemented upon, OBE took its maiden ride. Division of Academic Development and Quality consists of Professional Development and Talent Unit takes responsibility to develop, monitor and evaluate the effectiveness of academic programs while Focus Research Unit plans continuous quality improvement on the effectiveness of strategies, system and methodologies of academic management. Since 2010, these units collaborate with the Information Technology Unit and progressively connecting the academic delivery and the assessment tools to a system epithet as UPSI Integrated Management System (UIMS).

The measurement of achievement of CLO is a done prior to PLO, which later determines if the PEO is met. In this paper VAB3013 Agribotany, a newly introduced course designed for Bachelor of Education (Agricultural Science) with Honours program is used as an example. This paper is also aimed to share the achievement of UIMS to simplify the process of Student Learning Outcome Monitoring (SLOM). Eventually Course Learning Outcome (CLOM) is automatically calculated. The performances of all CLOMs in a program which have been mapped to the PLOs are analysed. Ultimately the Program Educational Objective (PEO) performance of the Bachelor of Education (Agricultural Science) with Honours graduates is evaluated. The tools; SLOM, CLOM, PLO and PEO are developed by UPSI in order to support the process of OBE implementation and to ease the documentation.

\section{IMPLEMENTATION OF OUTCOME BASED EDUCATION}

The definitions of PEO, PLO and CLO are as below and they are to be evaluated to measure the achievement of a program.

\section{Program Educational Outcomes (PEO):}

Program Educational Objectives are broad statements that describe what students are expected to know and able to perform upon graduation that the program is preparing graduates to achieve; in other words the career and professional accomplishments. These relate to three domains; cognitive (knowledge), affective (behavior and soft skills) and psychomotor (skills).

Program Learning Outcomes (PLO):

Program Learning Outcomes are narrower statements that describe what students are expected to know and be able to do by the time of graduation. These relate to the skills, knowledge, and behaviors that students acquire in their matriculation through the program.

\section{Course Learning Outcomes (CLO)}

The definition used for the Course Learning Outcomes is narrower statements made of Performance Criteria which describe what students are expected to know and be able to do at the end of the course.

In Bachelor of Education (Agricultural Science) with Honours program, Student Learning Outcome (SLO), Course Learning Outcome (CLO) and Program Learning Outcome (PLO) are evaluated. The PLOs are constructed based on the eight criteria listed in MQA Framework; knowledge, skill, community engagement, Information Communication Technology, problem solving, leadership and lifelong learning and entrepreneurship. 
The mechanism start with planning the PEO (Table 1), followed by the mapping the PLO to the PEO (Table 2). Subsequently, CLOs are mapped to the PLOs (Table 3). Table 4 displays the courses in the component of discipline core, which include VAB3013 Agribotany that are mapped to the PLO.

Table 1: Bachelor of Education (Agricultural Science) with Honours Program Educational Objective (PEO)

\begin{tabular}{|c|l|}
\hline $\begin{array}{c}\text { Program Educational } \\
\text { Objective (PEO) }\end{array}$ & Graduate Attributes \\
\hline PEO1 & $\begin{array}{l}\text { Knowledgeable, skillful and competent in the field of Agricultural Science to meet } \\
\text { the needs of teachers in secondary schools, technical schools and community } \\
\text { colleges/ polytechnics, } \\
\text { Fulfill the demand of employment in the agricultural sectors such as agricultural } \\
\text { extension officer, manager or trainer, }\end{array}$ \\
\hline PEO2 & $\begin{array}{l}\text { Positive attitude, analytical to the teaching profession, exhibits a great personality } \\
\text { and committed to the teaching profession, }\end{array}$ \\
\hline PEO3 & $\begin{array}{l}\text { Implement ethics and social responsibility } \\
\text { Sensitive to current issues in agriculture and involve actively in research and } \\
\text { development }\end{array}$ \\
\hline PEO4 & Equipped with entrepreneurial knowledge and experience. \\
\hline
\end{tabular}

Table 2: Bachelor of Education (Agricultural Science) with Honours Program Learning Outcome (PLO)

\begin{tabular}{|c|c|}
\hline $\begin{array}{l}\text { Program Learning } \\
\text { Outcome (PLO) }\end{array}$ & Graduate Attributes \\
\hline PLO1 & $\begin{array}{l}\text { Master the knowledge and pedagogy in the field of Agricultural Sciences. } \\
\text { (Knowledge) }\end{array}$ \\
\hline PLO2 & Apply the skills in agricultural practices. (Skills) \\
\hline PLO3 & Engage in community and social work. (Community engagement) \\
\hline PLO4 & Embrace the leadership and attitude and ethical behaviour.(Leadership) \\
\hline PLO5 & $\begin{array}{l}\text { Communicate creatively in a team to generate ideas and critically evaluate issues } \\
\text { related to the field of agricultural science. (Communication) }\end{array}$ \\
\hline PLO6 & $\begin{array}{l}\text { Engage in research, problem solving and scientific writing in the field of Agricultural } \\
\text { Sciences. (Problem solving) }\end{array}$ \\
\hline PLO7 & $\begin{array}{l}\text { Master the technical skills, including the use of educational technology and ICT in } \\
\text { teaching and managing information and lifelong learning of Agricultural } \\
\text { Sciences.(Information Communication Technology) }\end{array}$ \\
\hline PLO8 & $\begin{array}{l}\text { Utilize the knowledge, skills and knowledge in agricultural business. :(Lifelong } \\
\text { learning and entrepreneurship) }\end{array}$ \\
\hline
\end{tabular}

Table 3: Mapping the Program Learning Outcome (PLO) to Program Educational Objective (PEO)

\begin{tabular}{|c|c|c|c|c|c|c|c|}
\hline & Program Learning Outcome (PLO) & PEO1 & PEO2 & PEO3 & PEO4 & PEO5 & $\begin{array}{c}\text { PEO } \\
6\end{array}$ \\
\hline 1 & $\begin{array}{l}\text { Master the knowledge and pedagogy in the field of } \\
\text { Agricultural Science }\end{array}$ & l & 1 & 1 & & & I \\
\hline 2 & Apply the skills in Agricultural practices & 1 & 1 & & & 1 & 1 \\
\hline 3 & Engage in community and social work & 1 & & & 1 & & \\
\hline 4 & $\begin{array}{l}\text { Embrace the leadership and attitude and ethical } \\
\text { behaviour. }\end{array}$ & l & & & I & & I \\
\hline 5 & $\begin{array}{l}\text { Communicate creatively in a team to generate ideas } \\
\text { and critically evaluate issues related to the field of } \\
\text { Agricultural Science }\end{array}$ & l & 1 & l & & I & 1 \\
\hline 6 & $\begin{array}{l}\text { Engage in research, problem solving and scientific } \\
\text { writing in the field of Agricultural Science }\end{array}$ & l & 1 & I & & I & \\
\hline 7 & $\begin{array}{l}\text { Master the technical skills, including the use of } \\
\text { educational technology and ICT in teaching and } \\
\text { managing information and lifelong learning of }\end{array}$ & 1 & 1 & 1 & & I & \\
\hline
\end{tabular}




\begin{tabular}{|c|l|l|l|l|l|}
\hline & Agricultural Science & \\
\hline 8 & $\begin{array}{l}\text { Master the knowledge and pedagogy in the field of } \\
\text { Agricultural Science }\end{array}$ & & 1 & 1 \\
\hline
\end{tabular}

All courses including VAB3013 Agribotany are then mapped to Program Learning Outcome (PLO). It serves as a checklist to ensure upon graduation, students are equipped with all the attributes in Program Educational Outcomes (PEOs).

Table 4: Mapping of Discipline Core Courses to the PLO

\begin{tabular}{|c|c|c|c|c|c|c|c|c|c|}
\hline Code & Course & $\begin{array}{l}\text { PLO } \\
1\end{array}$ & $\begin{array}{l}\text { PLO } \\
2\end{array}$ & $\begin{array}{l}\text { PLO } \\
3\end{array}$ & $\begin{array}{l}\text { PLO } \\
4\end{array}$ & $\begin{array}{l}\text { PLO } \\
5\end{array}$ & $\begin{array}{l}\text { PLO } \\
6\end{array}$ & $\begin{array}{l}\text { PLO } \\
7\end{array}$ & $\begin{array}{l}\text { PLO } \\
8\end{array}$ \\
\hline VAA3013 & Livestock Production & I & I & & & 1 & I & I & 1 \\
\hline VAA3023 & Aquaculture & I & I & & & I & I & I & I \\
\hline VAB3013 & Agribotany & 1 & 1 & 1 & & 1 & 1 & 1 & \\
\hline VAC3013 & Annual Crops & 1 & 1 & & & 1 & 1 & 1 & 1 \\
\hline VAC3043 & Farm Management & 1 & 1 & & 1 & 1 & 1 & 1 & 1 \\
\hline VAC3053 & Fruit Production & 1 & 1 & & & 1 & 1 & 1 & 1 \\
\hline VAC3063 & Industrial Crop & 1 & 1 & & & 1 & 1 & 1 & 1 \\
\hline VAE3013 & $\begin{array}{l}\text { Supervised Occupational } \\
\text { Experience Program }\end{array}$ & I & I & I & 1 & I & / & I & l \\
\hline VAE3033 & Agribusiness & I & I & l & 1 & 1 & I & I & I \\
\hline VAH3013 & $\begin{array}{l}\text { Plant Propagation and Nursery } \\
\text { Management }\end{array}$ & I & I & & & I & I & I & I \\
\hline VAH3023 & $\begin{array}{l}\text { Ornamental Plants and } \\
\text { Landscape }\end{array}$ & I & / & & & I & I & I & l \\
\hline VAM3023 & Farm Mechanization & 1 & 1 & & & 1 & 1 & 1 & 1 \\
\hline VAP3023 & Pest Control & I & 1 & & & 1 & I & I & 1 \\
\hline VAR3013 & $\begin{array}{l}\text { Statistics for Agricultural } \\
\text { Research }\end{array}$ & I & l & & 1 & I & / & I & \\
\hline VAS3013 & Soil Science & 1 & 1 & & & 1 & 1 & 1 & \\
\hline VAT3013 & Post Harvest Technology & 1 & 1 & & & 1 & 1 & 1 & 1 \\
\hline VAR3996 & Final Year Project & l & I & 1 & I & I & I & I & I \\
\hline
\end{tabular}

The VAB3013 Agribotany course learning outcomes (CLOs) are constructed to measure students' achievements for all the three domains; namely Cognitive, Affective and Psychomotor and listed as below.

CLO1: Describe the basic botany (morphology, anatomy, physiology, taxonomy) in agriculture. (Cognitive Level: Analysis)

CLO2: Distinguish the anatomical and morphological structures of monocotyledon and dicotyledon plants. (Cognitive Level: Application).

CLO3: Construct anatomy and taxonomy with the function of a variety of dicotyledon and monocotyledon plants. (Cognitive Level: Analysis and Psychomotor Level: Adaptation)

CLO4: Apply the cooperation in teamwork. (Affective Level: Organizing Values, Soft Skill Level: Teamwork)

\section{UPSI INTEGRATED MANAGEMENT SYSTEM (UIMS)}

UPSI's Information, Communication and Technology Unit developed UPSI Integrated Management System: Student Information System epithet as UIMS: MySIS (Fig. 1). 
UNIVERSITI PENDIDIKAN SULTAN IDRIS

\section{Guims}

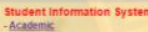

Student intomention Sytari

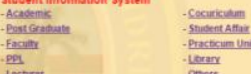

Syatem admin

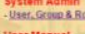

tection

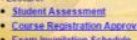

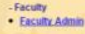

$=-2-1-10$

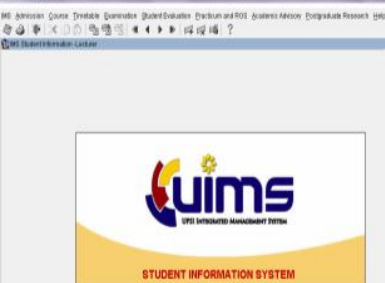

Fig. 1 Introductory page of MySIS

PLOs, PEOs, CLOs are entered using another platform MyUPSI Portal (Fig. 2) which has been developed for many purposes such as a human resource portal, finance portal, E-meeting portal, administration portal and also a portal for teaching and learning activities (MyGuru $\left.{ }^{2}\right)$. MyGuru ${ }^{2}$ is linked to MySIS (Fig. 3).

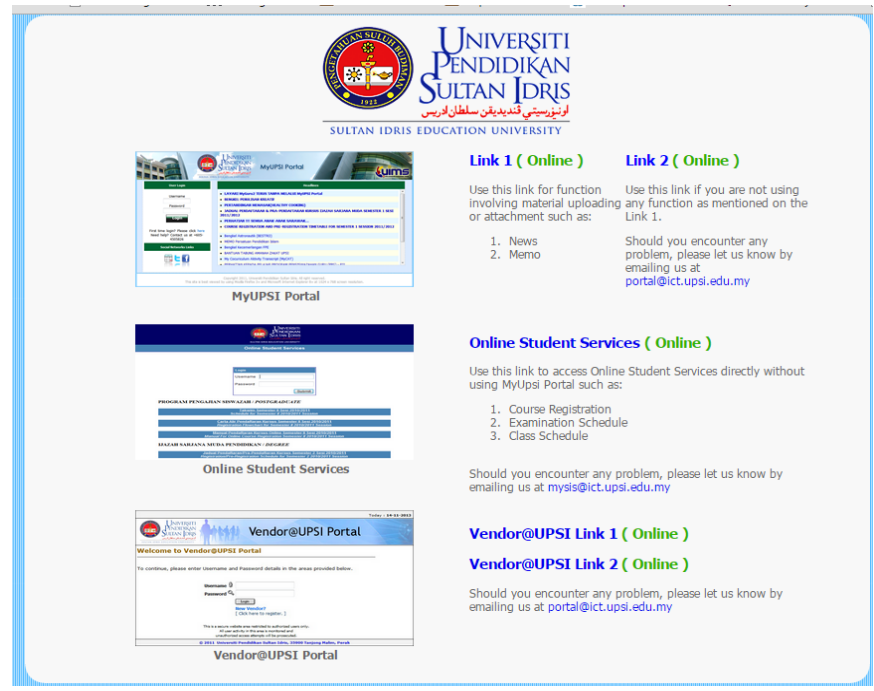

Fig. 2 Introductory page of MyUPSI Portal

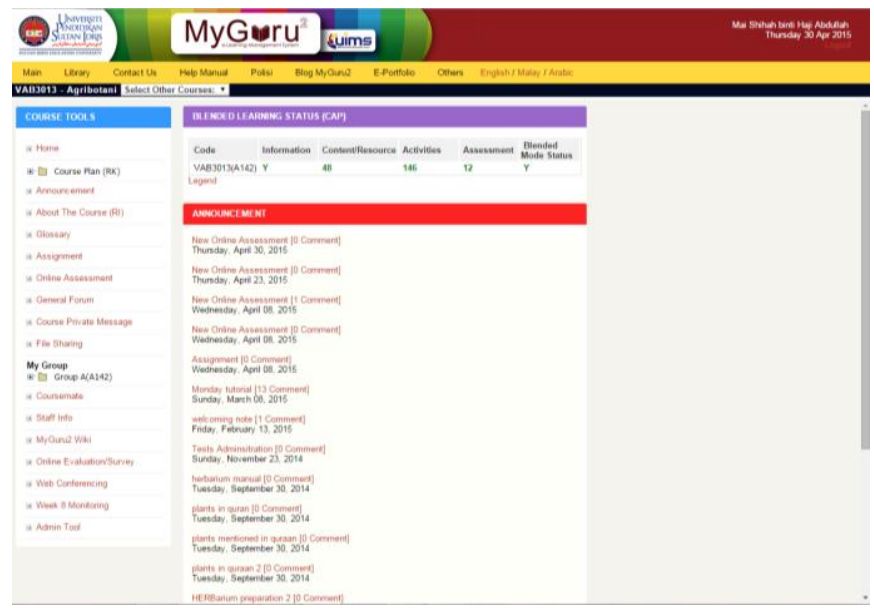

Fig. 3 (a) MyGuru²: Learning and Teaching Portal 


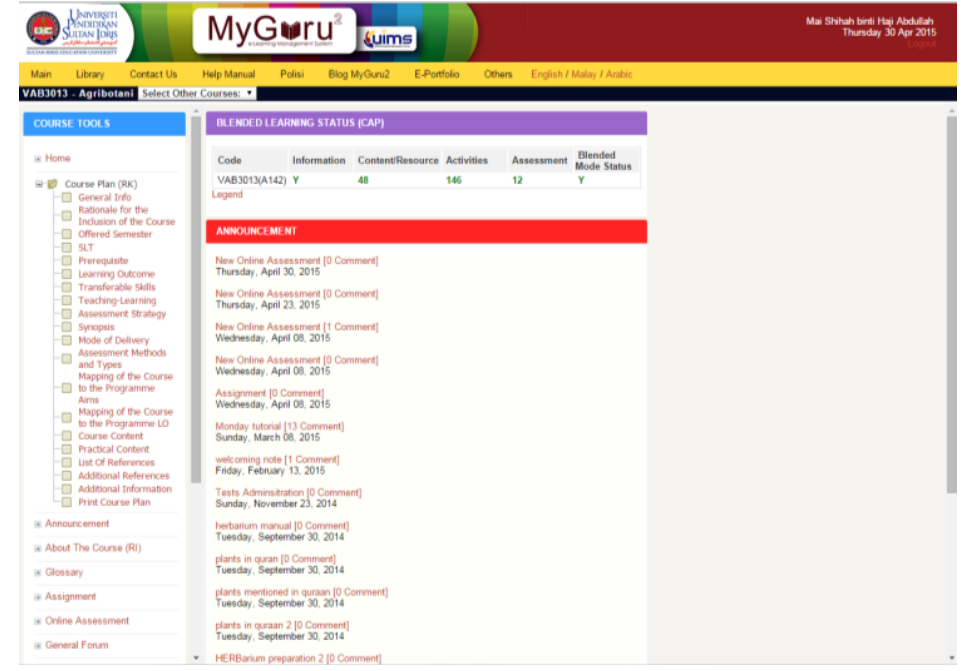

Fig. 3 (b) MyGuru² Interface for PEO, PLO and CLO mappings

At the beginning of a semester, the lecturer cum the course coordinator is to set up the mark distributions and type for all the assessments and aligned them to the learning outcomes (Fig. 4).

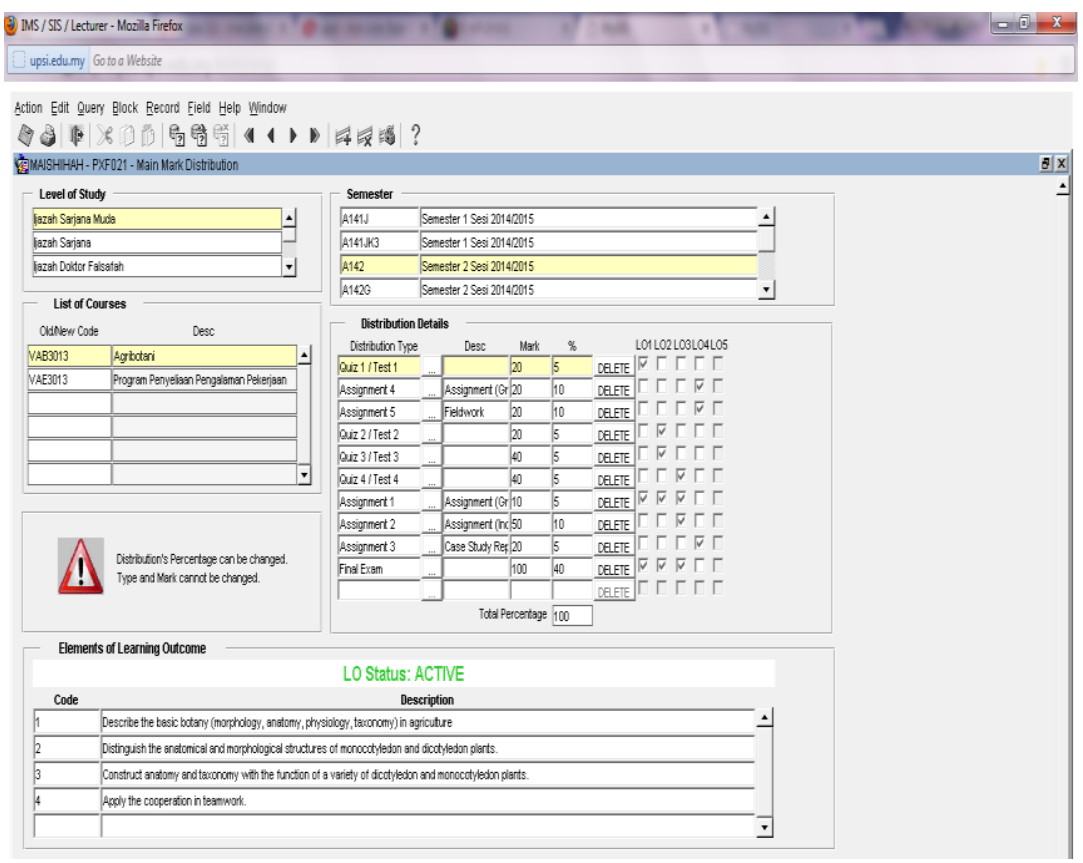

Fig. 4 Marks distribution set up for each type of assessment and aligns to course learning outcome

\section{MONITORING}

When all mappings are done accordingly, monitoring is carried out to measure the achievement of course via OBE. At UPSI, monitoring report is to be conducted and verified by the Head of Department in week 8 as shown in Fig. 5. 


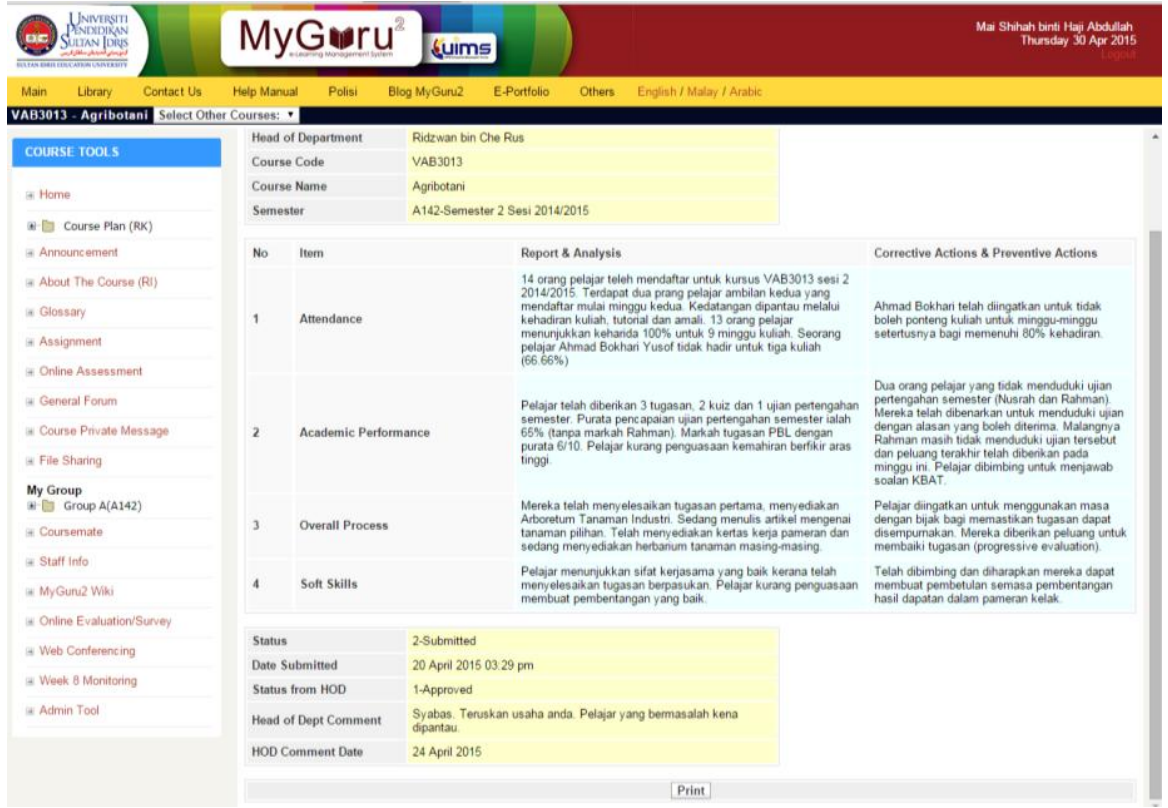

Fig. 5 Eighth week monitoring report

\section{LEARNING EVALUATION}

At the end of the semester (week 14), learning evaluation survey is carried out by the students. The outcome of the survey as displayed in Fig. 6 .

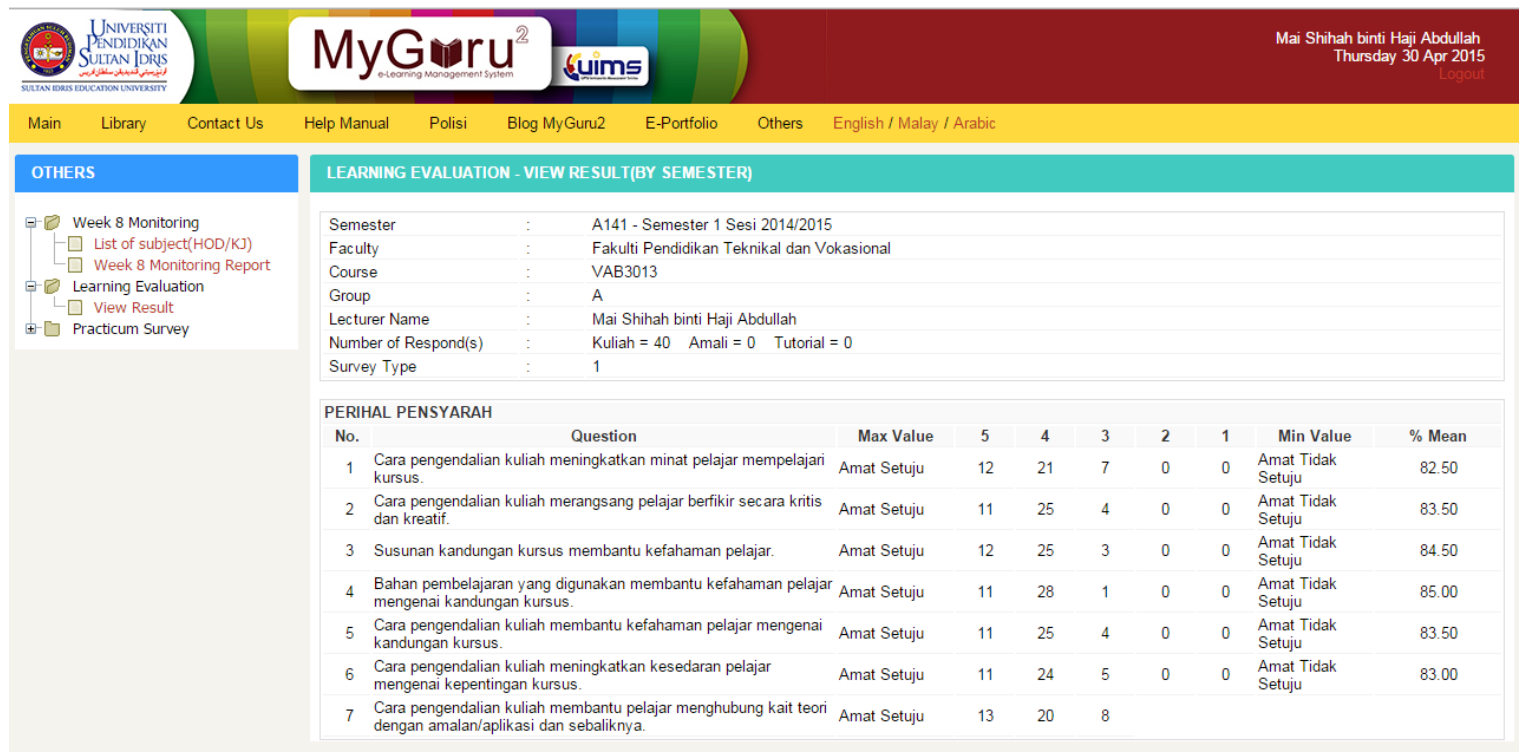

Fig. 6 Learning evaluations of VAB3013 Agribotany

\section{INTEGRATION OF MYGURU ${ }^{2}$ AND MYSIS}

The flowchart in Fig. 7 outlines the integration of both platforms the MyGuru ${ }^{2}$ and MYSIS as enablers to assess the SLO, CLO, PLO and PEO. The process shown in Fig. 7 also outlines all steps a lecturer undertakes at the beginning of a semester for a particular course until the graduation of a cohort.

Having this facility, the lecturers at UPSI are more receptive to the paradigm shift to fulfill OBE needs. Time and energy are geared into monitoring and pursuing to implementing the recommendations made for Continuous Quality Improvements. 


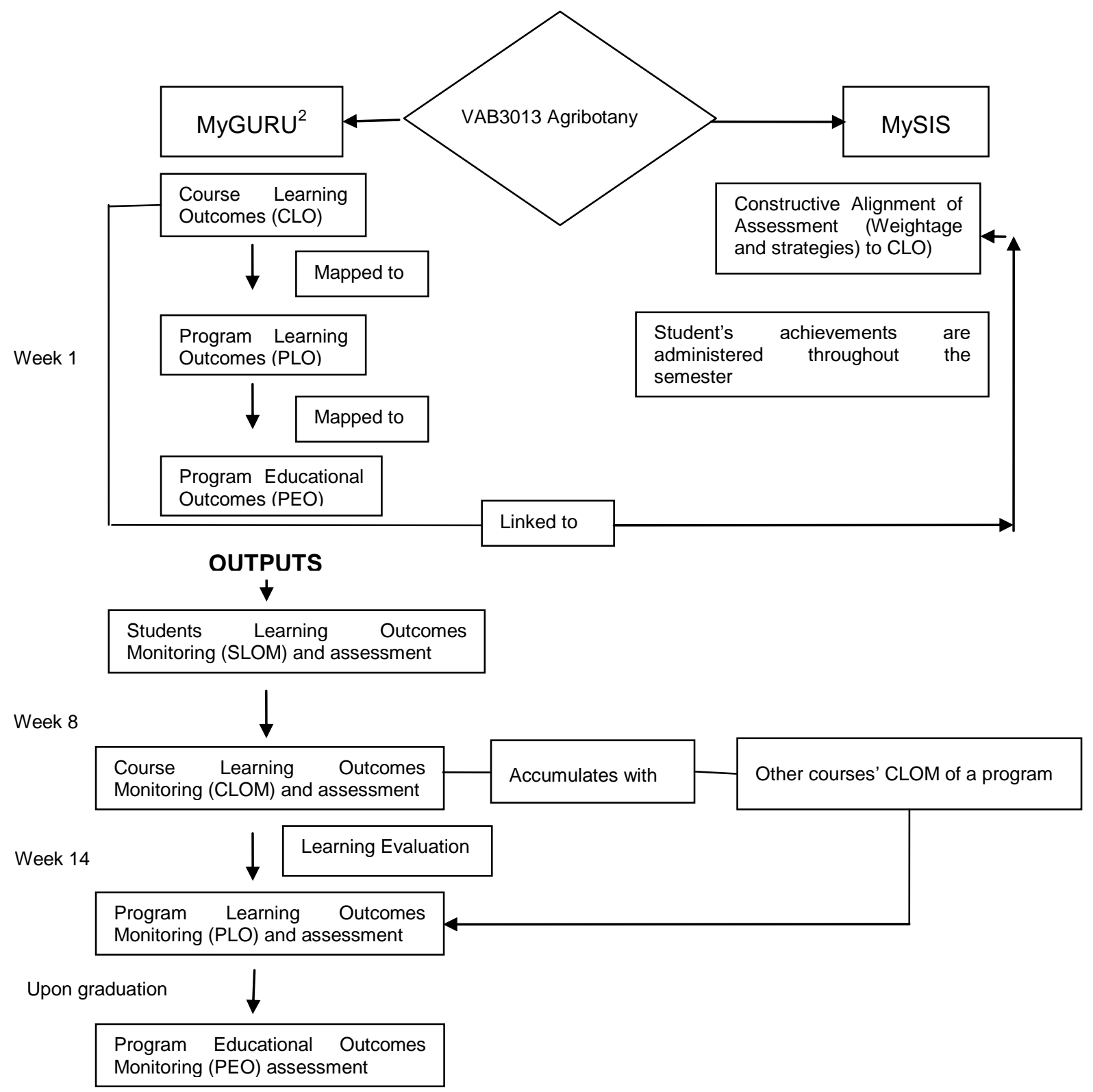

Fig. 7 Assessments of SLO, CLO, PLO, PEO and Learning Evaluation: An OBE Implementation at UPSI

The inputs that have been obtained from the last semester have been analyzed and VAB3013 Agribotany is used as a sample to exhibit the OBE implementation at UPSI.

\section{PERFORMANCE OF VAB3013 AGRIBOTANY VIA OBE}

VAB3013 Agribotany is a new course introduced in a reviewed curriculum of the Bachelor of Education (Agricultural Science) with Honours. Forty students registered for this course and their performance for each learning outcome is calculated and the learning outcome index is displayed (Fig. 8). Achievement of each learning outcome for VAB3013 is as follows; CLO 1 (72\%), CLO2 (72\%), CLO3 (76\%) and CLO4 (80\%) as in Fig. 9. 


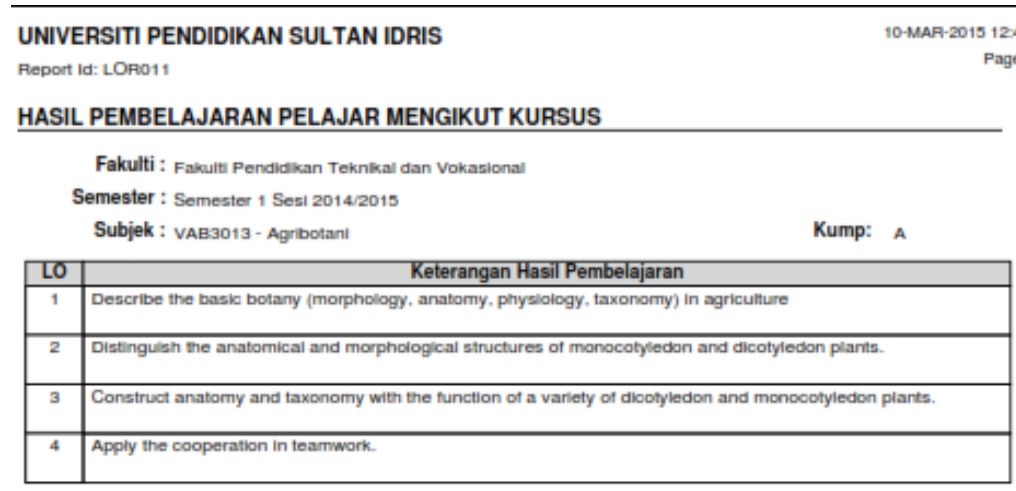

\begin{tabular}{|c|c|c|c|c|c|c|c|c|c|c|}
\hline BतT & TdPelajar & Nama Pelajar & $\begin{array}{l}\text { LOI } \\
(\%)\end{array}$ & $\begin{array}{l}\mathrm{LO} 2 \\
(\%)\end{array}$ & {$\left[\begin{array}{l}\mathrm{LO} 3 \\
(\%)\end{array}\right]$} & $\begin{array}{l}\mathrm{LOH} \\
(\%)\end{array}$ & $\begin{array}{l}\text { L05 } \\
(\%)\end{array}$ & $\begin{array}{l}\text { LO } \\
\text { Index }\end{array}$ & $\begin{array}{l}\text { Exam } \\
\text { Marks }\end{array}$ & Gred \\
\hline 1 & D20141006799 & AHMAD HAKIMI BIN OTHMAN & 79.30 & 73.30 & 76.30 & 79.6 & & 77.2 & 72 & B+ \\
\hline 2 & D20141006786 & $\begin{array}{l}\text { ASMAA NABILAH BINTI MOHAMAD } \\
\text { ASPI }\end{array}$ & 82.30 & 73.88 & 80.36 & 83.12 & & 79.9 & 74 & B+ \\
\hline 3 & $D 20141000800$ & BEEE NAZIRAH BINTI HASHIM & $\infty 0.30$ & 03.50 & 74.50 & 70.6 & & 70.3 & 64 & B- \\
\hline 4 & 020141000811 & FAIZAH BINTI NOR AZHARI & 78.12 & 72.12 & 70.6 & 80.68 & & 76.9 & 71 & $8+$ \\
\hline 5 & 020141000792 & FATIN NADIA GINTI REDZUAN & 63.24 & 64.84 & 72.30 & 78.4 & & 69.7 & 60 & B. \\
\hline 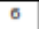 & D20141006812 & IDA FAFHANI BINTI JUMA'AT & 75.44 & 71.30 & 74.84 & 77.4 & & 74.8 & 70 & B+ \\
\hline 7 & 020141006807 & $\begin{array}{l}\text { LIYANA AFIOAH BINTI ABD } \\
\text { RAHMAN }\end{array}$ & 64.08 & 77.10 & 74.10 & 76.28 & & 72.9 & 70 & $\mathrm{~B}+$ \\
\hline 8 & 020141000805 & MARYAM NURAIN BINTI APENDI & 71.12 & 68.52 & 71.52 & 75 & & 71.5 & 65 & $\bar{B}$ \\
\hline 9 & 020141006785 & MIOA IDRIS BIN AHMAD HALIM & & & & 3 & & 75.8 & $\overline{60}$ & B \\
\hline
\end{tabular}

Fig. 8 Extract of students learning outcome performance for VAB3013

\section{UNIVERSITI PENDIDIKAN SULTAN IDRIS}

\section{LEARNING OUTCOMES ( LO ) ASSESSMENT \\ BACHELOR OF EDUCATION SEMESTER 1 SESSION 2014/2015}

Course : VAB3013 - Agribotany

Learning Outcome Result

\begin{tabular}{|c|l|c|c|}
\hline LO & \multicolumn{1}{|c|}{ Description of Learning Outcome } & Type Of Assessment & Index \\
\hline LO1 & $\begin{array}{l}\text { Describe the basic botany (morphology, anatomy, physiology, taxonomy) in } \\
\text { agriculture }\end{array}$ & $72 \%$ \\
\hline LO2 & $\begin{array}{l}\text { Distinguish the anatomical and morphological structures of monocotyledon and } \\
\text { dicotyledon plants. }\end{array}$ & $72 \%$ \\
\hline LO3 & $\begin{array}{l}\text { Construct anatomy and taxonomy with the function of a variety of dicotyledon } \\
\text { and monocotyledon plants. }\end{array}$ & $76 \%$ \\
\hline LO4 & Apply the cooperation in teamwork. & $80 \%$ \\
\hline
\end{tabular}

$\begin{array}{ll}\text { Overall Archievement } & : 75 \% \\ \text { Number of Student Failed } & : 0\end{array}$

\section{Suggestion for Continuous Improvement}

Hasil pembelajaran telah dicapai secara keseluruhannya.

Pelajar akan diberikan penekanan kepada menjalankan pembelajaran kendiri untuk meningkatkan penguasaan untuk menerangkan fisiologi, morfologi dan anatomi tumbuhan yang digunakan dalam pertanian.

Mempelbagaikan strategi $\mathrm{P}$ dan $\mathrm{P}$ contohnya pembentangan hasil dari kertas kajian tumbuhan dalam pertanian.

Fig. 9 Course Learning Outcome for VAB3013 Agribotany

The key performance index ranking indicates as weak if a score falls in the range of $(0-49 \%)$, moderate (50 
- 64\%) and strong (65 - 100\%). As shown above, four CLOs addressed by this course had achieved CLO score at $75 \%$ which is prevailed as strong. Therefore, the average of this cohort of students has shown strong attributes in all prescribed CLOs.

\section{CONTINUOUS QUALITY IMPROVEMENTS}

The scores for each student as shown in SLOM and as well as each course learning outcome in CLOM both provide avenue for the lecturer to strategize for future improvement after a post mortem has been carried out. Students in this course have been observed to have strongly achieved $(80 \%)$ for CLO 4: cooperation in team work and soft skills whereby they achieved only $72 \%$ for CLO 1 and CLO2.

Thus, the recommendations for improvement for the next cohort of students should include self-study and more laboratory work to examine the anatomy and morphology of the plants. Subsequently, students' should conduct an analysis on basic botany by project oriented problem based learning strategy and also by preparing a mini research paper on agricultural plants.

\section{CONCLUSION AND FURTHER RECOMMENDATIONS}

The evaluation ofOBE implemented at UPSI which was once perceived as complicated, time and energy consuming is now reduced by the integration of MyGuru ${ }^{2}$ that is linked to University Integrated Management System (UIMS). This is one of the few user-friendly tools, developed to facilitate the academia for OBE evaluation in Malaysia.

UIMS and MyGURU ${ }^{2}$ can be improved by enhancing certain features such as adding more choices for the type of teaching and learning strategies and assessments. At the same time more columns are required to key in the breakdown of an assessment that is mapped for a multiple domains in one learning outcome.

\section{ACKNOWLEDGEMENT}

The author would like to thank the Division of Academic Development and Quality (BPAQ) and Information, Communication and Technology Unit (ICTU), Sultan Idris Education University for the permission to utilize the graphics and data generated from both MyGuru ${ }^{2}$ and MySIS.

\section{REFERENCE LIST}

Spady, W. G. (1998). Organizing for results: the basis of authentic restructuring and reform. Educational Leadership, 46:2, pp. 4-8.

Spady, W. G., \& Marshall, K. J. (1991). Beyond traditional outcome-based education. Educational Leadership, 49:2, pp. 67-72. 